\title{
Proteome of exhaled breath condensate on exposure to high-temperature thermoheliox
}

\author{
S. D. Varfolomeev, ${ }^{a, b}$ A. A. Panin, ${ }^{c}$ A. M. Ryabokon, ${ }^{b, d \star}$ A. S. Kozyr, ${ }^{b}$ A. S. Kononikhin, ${ }^{b}$ \\ L. V. Shogenova, ${ }^{e}$ and A. G. Chuchaline \\ ${ }^{a}$ Institute of Physicochemical Foundations of the Functioning of \\ Neural Networks and Artificial Intelligence, M. V. Lomonosov Moscow State University, \\ Build. 11B, 1 Leninskie Gory, 119991 Moscow, Russian Federation. \\ Fax: +7 (499) 9393589 \\ ${ }^{b}$ N. M. Emanuel Institute of Biochemical Physics, Russian Academy of Sciences, \\ 4 ul. Kosygina, 119334 Moscow, Russian Federation. \\ Fax: +7(499) 137 4101. E-mail: amryabokon@gmail.com \\ ${ }^{c}$ LLC MedTechInnovations, \\ 3-1 Blagoveshchenskii per., 123001 Moscow, Russian Federation \\ ${ }^{d}$ Department of Chemistry, M. V. Lomonosov Moscow State University, \\ Build. 11B, 1 Leninskie Gory, 119991 Moscow, Russian Federation \\ ${ }^{e} N$. I. Pirogov Russian State National Research Medical University, \\ 1 ul. Ostrovityanova, 117997 Moscow, Russian Federation
}

\begin{abstract}
The proteome of exhaled breath condensate was analyzed by mass spectrometry before and immediately after the thermoheliox procedure and after a $3 \mathrm{~h}$ relaxation. The major part of the proteome remained unchanged and there was no extensive cell destruction.
\end{abstract}

Key words: thermoheliox, therapy, exhaled breath condensate, proteome, mass spectrometric analysis.

The high-temperature breathing mixture of helium and oxygen (thermoheliox) started to be actively used for the treatment of various diseases, in particular, chronic obstructive pulmonary disease, $\mathbf{1 , 2}$ ischemic stroke, ${ }^{\mathbf{3}}$ and some pathologies of pregnancy. It is relevant to use thermoheliox for the treatment of acute viral infections, including the coronavirus infection ${ }^{4}$ and to stimulate the human immune system. ${ }^{5}$ Meanwhile, the effect of thermoheliox on the human body appears to be complex and requires additional investigations. The key question that should be answered first of all is whether or not high temperatures $\left(60^{\circ} \mathrm{C}\right.$ and above) have a significant detrimental effect on the cell structures of the respiratory system as the proteins of destroyed cells appear in the exhaled breath. In order to answer this question, we studied the composition of proteins in the human exhaled breath condensate (EBC) before and after the respiratory procedure carried out for $20 \mathrm{~min}$. The inhalation temperature at the inlet of the respiratory tract was $70^{\circ} \mathrm{C}$. The protein composition of the EBC after relaxation for $3 \mathrm{~h}$ was also studied for comparison.

\section{Experimental}

The exhaled breath condensate was collected by the traditional procedure using R-tube respiratory tubes (Respiratory
Research, USA). ${ }^{6,7}$ Liquid chromatography/mass spectrometry analysis (HPLC-MS/MS) was carried out using a system consisting of an Agilent 1100 chromatograph (Agilent Technologies Inc., USA) and an LTQ FT Ultra mass spectrometer (Thermo, Germany), according to previously published protocols. ${ }^{8}$ The list of exact masses of peptides and masses of their fragments was used to search and identify proteins from the database using the Mascot program (Matrix Science, London, UK; version 2.2.2). ${ }^{9}$ The proteins were identified according to the Swiss-Prot Human database taken from the UniProt freely accessible database of protein sequences (Switzerland).

\section{Results and Discussion}

Studying the protein content of EBC is an efficient method for diagnosis of various respiratory diseases. Previously, we utilized this method for the early diagnosis of lung cancer, ${ }^{10}$ chronic obstructive pulmonary disease, ${ }^{11}$ asthma, ${ }^{12}$ and biochemical processes accompanying lung transplantation. ${ }^{13}$ Determination of the protein content of the EBC was carried out for Russian cosmonauts who work on board the International Space Station before and after the flight. ${ }^{14}$

Studying of the effect of thermoheliox on the protein composition of EBC gave the following results. 
Table 1. The protein composition of the EBC before (I) and immediately after thermoheliox procedure (II) and after relaxation for $3 \mathrm{~h}$ (III)

\begin{tabular}{|c|c|c|}
\hline I & II & III \\
\hline Desmoglein-1-1 & Desmoglein-1 & Desmoglein-1 \\
\hline Cystatin-A & Cystatin-A & Cystatin-A \\
\hline $\begin{array}{l}\text { Immunoglobulin heavy } \\
\text { constant gamma } 1\end{array}$ & $\begin{array}{l}\text { Immunoglobulin heavy } \\
\text { constant gamma } 1\end{array}$ & $\begin{array}{l}\text { Immunoglobulin heavy } \\
\text { constant gamma } 1\end{array}$ \\
\hline Immunoglobulin gamma-1 heavy chain & Immunoglobulin gamma-1 heavy chain & Immunoglobulin gamma-1 heavy chain \\
\hline Immunoglobulin kappa constant & Immunoglobulin kappa constant & Immunoglobulin kappa constant \\
\hline Complement $\mathrm{C} 3$ & Complement $\mathrm{C} 3$ & Complement $\mathrm{C} 3$ \\
\hline Desmoplakin & Desmoplakin & Desmoplakin \\
\hline Keratin, type I cytoskeletal 17 & Keratin, type I cytoskeletal 17 & Keratin, type I cytoskeletal 17 \\
\hline Keratin, type I cytoskeletal 16 & Keratin, type I cytoskeletal 16 & Keratin, type I cytoskeletal 16 \\
\hline Dermcidin & Dermcidin & Dermcidin \\
\hline Keratin, type II cytoskeletal 5 & Keratin, type II cytoskeletal 5 & Keratin, type II cytoskeletal 5 \\
\hline Small proline-rich protein 3 & Small proline-rich protein 3 & Small proline-rich protein 3 \\
\hline Tubulin alpha-1C chain & Tubulin alpha-1C chain & - \\
\hline- & Fibrinogen beta chain & Fibrinogen beta chain \\
\hline- & Hemoglobin subunit alpha & Hemoglobin subunit alpha \\
\hline Calmodulin-like protein 5 & - & Calmodulin-like protein 5 \\
\hline Keratin, type II cytoskeletal 6B & Actin, cytoplasmic 2 & Desmocollin-1 \\
\hline- & Creatine kinase B-type & Glyceraldehyde-3-phosphate dehydrogenase \\
\hline- & 14-3-3 Protein zeta/delta & - \\
\hline- & Keratin, type I cytoskeletal 13 & - \\
\hline- & Actin, cytoplasmic 1 & - \\
\hline- & Apolipoprotein A-I & - \\
\hline- & Calmodulin-2 & - \\
\hline- & Calmodulin-3 & - \\
\hline- & Calmodulin-1 & - \\
\hline
\end{tabular}

1. After the thermoheliox procedure, the volume of the collected condensate $(1-1.5 \mathrm{~mL})$ decreases by, on average, $32 \%$ and is virtually restored after relaxation for $3 \mathrm{~h}$. The volunteers noted that breathing is easier after the procedure.

2. Data on the protein composition of EBC before and after the thermoheliox procedure and after the relaxation for $3 \mathrm{~h}$ are summarized in Table 1. The general pattern observed for all three samples was the same as found for all EBC samples collected from healthy volunteers. ${ }^{15}$ They include several immunoglobulin proteins, several keratin structural proteins, tubulin, and calmodulin. The general typical pattern is observed for samples before the thermoheliox procedure, immediately after the procedure, and after the relaxation for $3 \mathrm{~h}$. It is noteworthy that the immune system proteins (immunoglobulins, complement proteins) are always detected in EBC. The same proteins are found in $\mathrm{EBC}$ after thermoheliox procedure and after relaxation for $3 \mathrm{~h}$. It is known that immunoglobulins, first of all immunoglobulin A, are well represented in the mucosa. This is apparently responsible for their appearance in EBC.

3. The samples after the thermoheliox procedure contain small amounts of additional proteins. These are muscle metabolism proteins (actins and calmodulin), fibrinogen, and traces of hemoglobin, apolipoprotein, and creatine kinase B type. After the relaxation for $3 \mathrm{~h}$, tubulin is no longer detected in the EBC.
The results are presented in Fig. 1. One can see the areas of intersection and the number of different proteins: 15 proteins before the thermoheliox procedure (I), 24 pro-

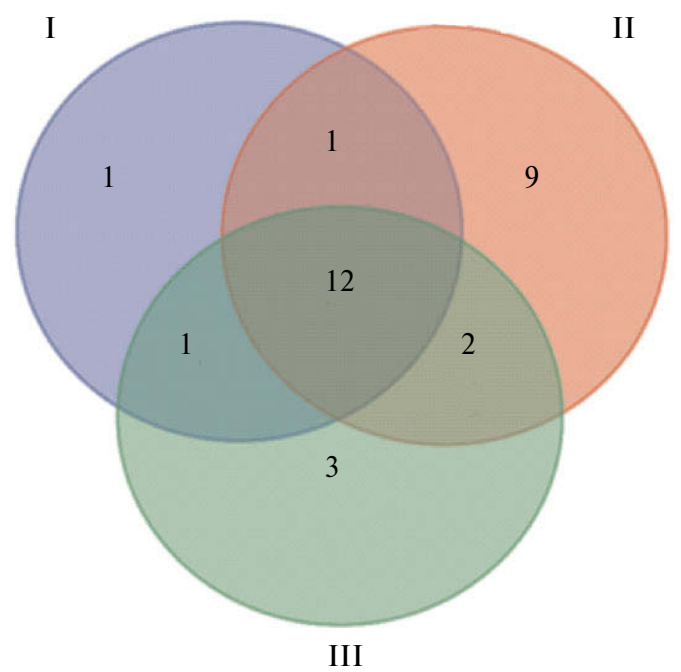

Fig. 1. Numbers of proteins in EBC samples before (I) and immediately after the thermoheliox procedure (II) and after relaxation for $3 \mathrm{~h}$ (III).

Note. Figure 1 is available in full color on the web page of the journal (https://link.springer.com/journal/volumesAndIssues/ 11172). 
teins immediately after the procedure (II), and 18 proteins after relaxation for $3 \mathrm{~h}$ (III).

The conducted experiments indicate that no dramatic destruction of cells with the transfer of large amounts of proteins to the exhaled breath takes place. A significant destruction of cells would give rise to hundreds of intracellular proteins, performing the whole range of metabolism, in the EBC. The numbers of exhaled proteins are mainly equal before and after the thermoheliox procedure and also after relaxation for $3 \mathrm{~h}$. The results demonstrate relative safety of the use of high-temperature thermoheliox as a therapeutic agent.

This work was financially supported by the Russian Foundation of Basic Research (Project No. 18-2909158 MK; mass spectrometric analysis of exhaled breathe condensate samples).

\section{References}

1. L. V. Shogenova, M. Ya. Godyaev, A. V. Tret'yakov, S. Yu. Novoselov, M. A. Kutsenko, A. A. Panin, A. G. Chuchalin, Moskovskaya Meditsina [Moscow Medicine], 2019, 2, 96 (in Russian).

2. L. V. Shogenova, M. Y. Godyaev, A. V. Tretyakov, A. A. Charapkin, S. Y. Novoselov, A. A. Panin, A. G. Chuchalin, T. G. Kim, Proc. Int. Conf. of ERS (Madrid, September 28October 2, 2019), Madrid, 2019, p. 110.

3. T. G. Kim, L. V. Shogenova, M. Yu. Martynov, E. M. Gusev, A. A. Panin, XXVIII Natsional'nyi Kongress Organov Dykhaniya (Moskva, 16-19 Oktyabrya 2018 g.) [XXVIII National Congress of Respiratory Organs (Moscow, October 16-19, 2018)], DizainPress, Moscow, 2019, pp. 71 (in Russian).

4. S. D. Varfolomeev, A. A. Panin, V. I. Bykov, S. B. Tsybenova, L. V. Shogenova, A. A. Chuchalin, Russ. Chem. Bull., 2020, 69, 1179.

5. S. D. Varfolomeev, A. A. Panin, V. I. Bykov, Russ. Chem. Bull., 2020, 69, 1811.

6. A. M. Ryabokon', E. Kh. Anaev, A. S. Kononikhin, N. L. Starodubtseva, G. Kh. Kireeva, I. A. Popov, E. N. Kukaev, V. V. Barmin, V. A. Bagrov, O. V. Pikin, E. N. Nikolaev, S. D. Varfolomeev, Pul'monologiya [Pulmonology], 2014, 1, 5-11 (in Russian).
7. E. Kh. Anaev, K. Yu. Fedorchenko, M. E. Kushaeva, A. M. Ryabokon, A. S. Kononikhin, V. V. Barmin, O. V. Pikin, I. A. Popov, E. N. Nikolaev, S. D. Varfolomeev, A. G. Chuchalin, Eur. Resp. J., 2017, 50, PA728; DOI: 10.1183/1393003. congress-2017.PA728.

8. A. S. Kononikhin, N. V. Zakharova, A. E. Iusupov, A. M. Ryabokon, K. Yu. Fedorchenko, M. I. Indeykina, A. E. Bugrova, A. I. Spassky, I. A. Popov, S. D. Varfolomeev, E. N. Nikolaev, Russ. J. Phys. Chem. B, 2019, 13, 951-955; DOI: https://doi.org/10.1134/S1990793119060216.

9. A. S. Kononikhin, K. Yu. Fedorchenko, A. M. Ryabokon, N. L. Starodubtceva, I. A. Popov, M. G. Zavialova, E. C. Anaev, A. G. Chuchalin, S. D. Varfolomeev, E. N. Nikolaev, Biochem. Suppl. Ser. B (Russian Federation), 2015, 61, No. 10, $230-234$

10. K. U. Fedorchenko, A. M. Ryabokon, A. S. Kononikhin, S. I. Mitrofanov, V. V. Barmin, O. V. Pikin, E. H. Anaev, I. V. Gachok, I. A. Popov, E. N. Nikolaev, A. G. Chuchalin, S. D. Varfolomeev, Moscow Univ. Chem. Bull., 2016, 71, No. 2, 134-139.

11. E. Kh. Anaev, M. E. Kushaeva, V. S. Kurova, A. M. Ryabokon', T. N. Anokhina, E. N. Nikolaev, S. D. Varfolomeev, A. G. Chuchalin, Pul'monologiya [Pulmonology], 2012, 5, 5-9 (in Russian).

12. E. Anaev, K. Fedorchenko, A. Ryabokon, M. Kushaeva, A. Kononikhin, E. Nikolaev, S. Varfolomeev, A. Chuchalin, Pneumologie, Georg Thieme Verlag, Germany, 2020, 74, S01, 64; DOI: 10.1055/s-0039-3403197.

13. V. S. Kurova, E. C. Anaev, A. S. Kononikhin, I. A. Popov, K. Yu. Fedorchenko, E. N. Nikolaev, S. D. Varfolomeev, A. G. Chuchalin, Russ. Chem. Bull., 2010, 59, 292.

14. A. S. Kononikhin, A. G. Brzhozovskiy, A. M. Ryabokon, K. Yu. Fedorchenko, N. V. Zhakharova, A. I. Spasskii, I. A. Popov, V. K. Ilyin, Z. O. Solovyova, L. Kh. Pastushkova, A. V. Polyakov, S. D. Varfolomeev, I. M. Larina, E. N. Nikolaev, Int. J. Mol. Sci., 2019, 20, 4518; DOI: 10.3390/ ijms20184518.

15. V. S. Kurova, A. M. Ryabokon', E. Kh. Anaev, A. G. Chuchalin, A. S. Kononikhin, I. A. Popov, E. N. Nikolaev, S. D. Varfolomeev, in: Post-genomnye Issledovaniya i Tekhnologii [Post-genomic Studies and Technologies], MAKS Press, Moscow, 2011, p. 174-202 (in Russian).

Received May 27, 2020; accepted June 23, 2020 